\title{
GIF NATURAL RADIOCARBON MEASUREMENTS II
}

\author{
G. DELIBRIAS, M. T. GUILLIER and J. LABEYRIE \\ Centre des Faibles Radioactivités, C.N.R.S. \\ Gif-sur-Yvette, Essonnes, France
}

The $\mathrm{C}^{14}$ dating laboratories of Saclay (Saclay I, 1964 and Saclay II, 1965) and Gif (Gif-sur-Yvette, 1966) have joined together under the name of $\mathrm{Gif}^{\mathrm{C}^{14}}$ Dating Laboratory. The first series of dating results appears here with code designation Gif, Sa now being obsolete.

Gif laboratory comprises 3 complete routine sets, each equipped with a $1.2 \mathrm{~L}$ proportional counter, filled with pure $\mathrm{CO}^{2}$ at $74 \mathrm{~cm} \mathrm{Hg}$ pressure, having backgrounds of $3.40,2.90$ and $1.60 \mathrm{cpm}$. The first two are of stainless steel and the third is of OFHC copper.

In accordance with the decision of the Fifth Radiocarbon Dating Conference, NBS oxalic acid is adopted as modern carbon reference, and the half-life $5570 \mathrm{yr}$ is used for age calculation.

Data listed here are part of those obtained from 1963, the date at which the first counter was calibrated, to October 1965.

\section{SAMPLE DESCRIPTIONS}

\section{ARCHAEOLOGIC SAMPLES}

\section{A. Western France}

Gif-166. Saint-Jude, Bourbriac, Côtes du Nord

Charcoal from an old burnt soil inside a tumulus at Saint-Jude, Bourbriac $\left(48^{\circ} 28^{\prime} \mathrm{N}\right.$ Lat, $3^{\circ} 18^{\prime} \mathrm{W}$ Long). Coll. 1962 and subm. by J. Briard and P. R. Giot, Lab. d'Anthropologie Préhistorique, Faculté des Sciences, Rennes, Ille et Vilaine. Comment: dates tumulus to Middle Bronze period.

\section{Gif-167. La Belle-Etoile, Saint-Connan, Côtes du Nord $\begin{array}{r}2350 \\ 400 \text { B.c. }\end{array}$}

Charcoal from habitat with heart at La Belle-Etoile, Saint-Connan (48 $25^{\prime} \mathrm{N}$ Lat, $3^{\circ} 04^{\prime} \mathrm{W}$ Long). Coll. 1960 and subm. 1962 by Mazeas and P. R. Giot. A stock of about 50 iron ingots has been found, hidden in ground. The hotsherds found can be ascribed to La Tène I (Giot, 1964). Comment: confirms the supposed period: La Tène I of the second Iron period.

\section{Gif-168. Plelauff, Côtes du Nord}

$1200 \pm 120$

Fragments of wood from gallery of ancient mine found at $36 \mathrm{~m}$ depth during mining prospection at Plélauff $\left(48^{\circ} 22^{\prime} \mathrm{N}\right.$ Lat, $3^{\circ} 13^{\prime} \mathrm{W}$ Long). Subm. by P. R. Giot. Comment: dates this ancient lead mine to the First-Middle-ages period. 
Créac'h-Kiliet series, Saint-Quay-Perros, Côtes du Nord

Charcoal from filling of Megalithic monument of Créac'h $\left(48^{\circ} 47^{\prime}\right.$ N Lat, $3^{\circ} 23^{\prime}$ W Long). Coll. and subm. 1963 by J. L'Helgouach, Lab. d'Anthropologie Préhistorique, Faculté des Sciences, Rennes, Ille et Vilaine.

Gif-197A. Créac'h-Kiliet A

$2850 \pm 170$

E extremity, Squares I-II, bottom.

900 B.C.

Gif-197B. Créac'h-Kiliet B

$2790 \pm 150$

W extremity, Center 5, bottom.

840 B.c.

Gif-197C. Créac'h-Kiliet C

$3470 \pm 200$

Lateral entrance.

Comment: possible partial contamination by infiltration of more recent coals, particularly during forest clearings of the Late Bronze period.

Tossen-Keler series, Penvenan, Côtes du Nord

Charcoal from tumulus of Tossen-Keler $\left(48^{\circ} 48^{\prime} \mathrm{N}\right.$ Lat, $3^{\circ} 33^{\prime} \mathrm{W}$ Long). Coll. and subm. by J. Briard and P. R. Giot.

Gif-237A. Tossen-Keler, Penvenan

$500 \pm 120$

Outer S hearth. Coll. and subm. 1963.

Gif-237B. Tossen-Keler, Penvenan

A.D. 1450

Central hearth. Coll. and subm. 1963.

$2700 \pm 200$

750 B.C.

Gif-280. Tossen-Keler, Penvenan

$4500 \pm 250$

E trench. Coll. and subm. 1964.

2550 B.C.

General Comment: Gif-280 is first dating of this Neolithic tumulus. Gif237A might be a filling with superficial ground containing charcoal; during Middle-age, hearth had been built at foot of some of the menhirs erected around tumulus.

Gif-283. Le Champ-Grosset, Quessoy, Côtes du Nord $\begin{array}{ll}\mathbf{3 8 2 0} \pm 200 & \mathbf{1 8 7 0} \text { в.c. }\end{array}$

Charcoal from Megalithic monument of the type "lateral entrance grave" found at Le-Champ-Grosset, Quessoy $\left(28^{\circ} 25^{\prime} 20^{\prime \prime} \mathrm{N}\right.$ Lat, $2^{\circ} 4^{\prime}$ $30^{\prime \prime} \mathrm{W}$ Long). Coll. and subm. 1964 by J. L'Helgouach. Comment: agreement with archaeological date (L'Helgouach and Le Roux, 1965).

Gif-158. Cleidern, Melgven, Finistère

$2170 \pm 140$

220 B.C.

Charcoal from filling of chest by 6 big flags, making a sepulture at Cleidern, Melgven $\left(47^{\circ} 54^{\prime} \mathrm{N}\right.$ Lat, $3^{\circ} 51^{\prime} \mathrm{W}$ Long). An intact three- 
handled vase has been identified as being of Middle Bronze period. Coll. by J. Briard and subm. 1962 by P. R. Giot. Comment: charcoal much too young for Bronze period.

\section{Ile de Geignog series, Landela, Finistère}

Charcoal from excavations of Megalithic monuments in island of Geingnog, $2 \mathrm{~km}$ off continent coast $\left(48^{\circ} 35^{\prime} \mathrm{N}\right.$ Lat, $4^{\circ} 35^{\prime} \mathrm{W}$ Long). Coll. by L'Helgouach; subm. 1962 by P. R. Giot. Neolithic potsherds have been discovered in these monuments which were re-used at late Bronze period. Traces of Late Bronze period still exist elsewhere in island. Monuments again occupied during Iron period (Giot, 1965).

Gif-161. Ile de Geignog

Room of Grave I A.

Gif-162. Ile de Geignog

Room of Grave II B.

Gif-163. Ile de Geignog

Room of Grave III A.

Gif-164A. Ile de Geignog

Bottom of room in Grave III B.

Gif-164B. Ile de Geignog skeleton.

Bottom of room in Grave III B, around and in incineration of a

\section{Gif-165. Ile de Geignog}

Bottom of room in Grave III C.

Gif-281. Ile de Geignog

Under the paving.

General Comment: coherent series of dates which confirms an important reutilization of these graves at Late Bronze period. Reutilizations explain connection of island with the continent at that period. Existence of a farm (findings of Mediaeval ceramics) in central part of island confirmed by Gif-163. Gif-165 is somehow ancient for Neolithic period but has already been found for other graves, Kercado (5840 $\pm 300, \mathrm{Sa}-95$, Saclay I). Gif-164B, somewhat too recent, may have been polluted by coals of Gif-164A origin.

\section{Lezommy series, Cléder, Finistère}

Charcoal from sepultures of Bronze period found at Lezommy, Cléder ( $48^{\circ} 37^{\prime} \mathrm{N}$ Lat, $4^{\circ} 09^{\prime} \mathrm{W}$ Long) . Without any apparent tumulus, 
graves were only covered with a big lump of stone. Classic industry of Middle Bronze period. Coll. and subm. 1963 by J. Briard and P. R. Giot.

Gif-188. Lezommy

$\mathrm{W}$ grave.

Gif-189. Lezommy

SE grave.
$3600 \pm 200$

1650 B.c.

$3150 \pm 200$

1200 B.c.

General Comment: $\mathrm{C}^{14}$ date corresponds to archaeological date.

\section{Pembrat-Vihan series, Lannilis, Finistère}

Charcoal from hearths near urns surrounding a quadrangular Gallic stele in a cemetery with cremation urns at Pembrat-Vihan $\left(48^{\circ} 26^{\prime} \mathrm{N}\right.$ Lat, $4^{\circ} 30^{\prime} \mathrm{W}$ Long). With implement from post-Hallstaat-La-Tène I. Coll. and subm. 1963 by C. T. Le Roux, Direction des Antiquités Préhistoriques, Rennes, Ille et Vilaine.

Gif-220A. Pembrat-Vihan A

Sample from mixture of all charcoal found.

Gif-220B. Pembrat-Vihan B

Hearth floor of Urn 3.

General Comment: ages too recent, not yet explained.

\section{Gif-238. Pointe de la Torche, Plomeur, Finistère A.D. 1370}

$1570 \pm 150$

A.D. 400

$$
1820 \pm 150
$$

A.D. 130

$$
580 \pm 120
$$

Marine shells of subfossil coastal line corresponding to highest present sealevel, Isthme de la Pointe de la Torche, Plomeur (44 $31^{\prime} \mathrm{N}$ Lat, $4^{\circ} 22^{\prime}$ W Long). Coll. and subm. 1963 by P. R. Giot and A. Guilcher, Institut de Géographie, Paris.

\section{Le Curnic series, Guissény, Finistère}

On beach of Curnic, Guissény, Finistère $\left(48^{\circ} 35^{\prime} \mathrm{N}\right.$ Lat, $4^{\circ} 25^{\prime} \mathrm{W}$ Long), charcoal found from hearths in pits, $0.50 \mathrm{~m}$ to $1 \mathrm{~m}$-depth with Bronze age salt-pan industry. Just under middle-level of sea. Coll. and subm. 1962 by P. R. Giot.

Gif-159. Le Curnic

E pit; charcoal.

Gif-160. Le Curnic W pit; charcoal.

Gif-278. Le Curnic

Sub-fossil wood from peat-bog in vicinity of site. Comment: peatbog, whose base is placed on loess, is a sediment of fresh water; pollen 
analysis (Van Zeist, 1963) shows presence of Nymphaea, Alba, Alisma, Sparganium, Typha, Augustifolia, indicating that sealevel was much lower than now (peat-bog is now immersed).

General Comment: Gif-159 and 160 complete first measurements for site, $3220 \pm 110$ в.P. (Gif-47C, Gif I) . Gif-160 is probably contemporary of salt-pan industry; 159 and $47 \mathrm{C}$ show that sub-fossil wood from peatbog may have been used as fuel in hearths.

\section{Gif-282. Le Correjou, Plouguerneau, Finistère}

$4250 \pm 250$

Charcoal found in a level of charcoal, $15 \mathrm{~m}$ thick, of a coastal peatbog at Plouguerneau, on beach of Correjou $\left(48^{\circ} 37^{\prime} \mathrm{N}\right.$ Lat, $4^{\circ} 31^{\prime} \mathrm{W}$ Long). Level is at present "mean" highest tide level. Coll. by C. T. Le Roux; subm. 1964 by P. R. Giot.

\section{Gif-249. Bois du Rocher, La Vicomté sur Rance, $\quad \mathbf{5 0 0 0} \pm \mathbf{3 0 0}$ \\ Côtes du Nord $\quad 3050$ B.c.}

Fragments of charcoal found in red clay $1 \mathrm{~m}$ thick, under $0.70 \mathrm{~m}$ sand-layer at a point in midst of Mousterian surface-workshop at Bois du Rocher ( $48^{\circ} 30^{\prime} \mathrm{N}$ Lat, $1^{\circ} 58^{\prime} \mathrm{W}$ Long). Coll. and subm. by M. Gruet, 78 bis, rue de Frémur, Angers. Comment: on same site is a Megalithic tomb; date shows that place was also a Neolithic settlement.

\section{Gif-195. Mané-er-Hloch, Locoal-Mendon, Morbihan}

$$
1970 \pm 120
$$

20 B.c.

Charcoal from angled passage grave at Mané-er-Hloh, Locoal-Mendon ( $47^{\circ} 43^{\prime} \mathrm{N}$ Lat, $3^{\circ} 07^{\prime} \mathrm{W}$ Long). Coll. 1924 by Le Rouzic; subm. by l'Hergouach. Comment: re-utilization of grave during Iron period.

\section{Gif-196. Ile de Téviec, Saint-Pieere, Quiberon, $\quad 2230 \pm 150$ Morbihan \\ 280 B.c.}

Ashy ground from excavations of Mesolithic site of Ile de Téviec at Saint-Pierre Quiberon (47 $33^{\prime} \mathrm{N}$ Lat, $3^{\circ} 18^{\prime} \mathrm{W}$ Long). Coll. and subm. 1963 by P. R. Giot. Comment: Late Mesolithic age expected archaeologically out evident contamination probably due to "Guano" of sea-birds.

\section{Le Castellic series, Carnac, Morbihan}

Coal of oak from low Neolithic long barrow at Le Castellic $\left(47^{\circ}\right.$ $34^{\prime}$ N Lat, $3^{\circ} 25^{\prime}$ W Long) . Coll. 1922 by Z. Le Rouzic and S. J. Péquart; subm. by J. l'Helgouach.

Gif-198A. Le Castellic, A

Large hearth No. 13, E Zone.

1980 B.C.

Gif-198B. Le Castellic, B

$5025 \pm 300$

Chest No. 3, W Zone.

3075 B.c. 
Comment: indicates that $\mathrm{W}$ zone with chests is of Early Middle Neolithic period while $\mathrm{E}$ zone, which is composed of only 3 hearths, seems to have been added at end of Neolithic period.

Gif-227. Ile de Hoëdic, Morbihan

$6575 \pm 350$

4625 B.c.

Well-known Mesolithic layer in island of Hoëdic $\left(47^{\circ} 20^{\prime} 35^{\prime \prime} \mathrm{N}\right.$ Lat, $2^{\circ} 53^{\prime} 04^{\prime \prime} \mathrm{W}$ Long) (Péquart, 1954). Archaeological layer where coal has been found lies closely on rocky base and is covered with marine sand eolian deposit, maximum height $2 \mathrm{~m}$. Also found in this layer: many fragments of shells, necropolis, and set of goods of Mesolithic period. Coll. 1962 and subm. 1963 by Y. Rollando, Conservateur du Musée Archéologique de la Société Polymathique du Morbihan, Vannes, Morbihan. Comment: dates Mesolithic period in Bretagne, showing that it is younger in Bretagne than at other Mesolithic stations in W Europe.

$725 \pm 120$

Gif-228. Ile de Boëde-en-Séné, Morbihan

A.D. 1225

Charcoal from salt-pan kiln of $\mathrm{S}$ coast of island of Boëde-en-Séné ( $47^{\circ} 36^{\prime} 15^{\prime \prime} \mathrm{N}$ Lat, $2^{\circ} 45^{\prime} \mathrm{W}$ Long). Coll. and subm. 1963 by J. Lejards, Société Polymathique du Morbihan, Vannes, Morbihan.

\section{Gif-229. Moustérian-en-Séné, Morbihan}

$1495 \pm 150$

Charcoal from kiln of salt-pan of station of Moustérian-en-Séné $\left(47^{\circ}\right.$ $36^{\prime} 10^{\prime \prime} \mathrm{N} \mathrm{Lat}, 2^{\circ} 44^{\prime} 30^{\prime \prime} \mathrm{W}$ Long), situated at coast of Gulf of Morbihan; kilns are covered with vegetable ground layer, 25 to $30 \mathrm{~cm}$ thick. Coll. and subm. 1963 by J. Lejards. Comment: age seems rather young for such stations, usually known as Gallic or Roman-Gallic. Near kiln, fragments of common vases of "La Tène" period were found.

\section{Gif-235. Tuchenn Gruguel, Guidel, Morbihan}

$\mathbf{3 2 7 0} \pm \mathbf{2 0 0}$

Charcoal from ground of tumulus of Old Bronze period at Tuchenn Cruguel ( $47^{\circ} 46^{\prime} \mathrm{N}$ Lat, $3^{\circ} 13^{\prime} \mathrm{W}$ Long); 4 daggers, 1 hatchet, 14 arrows found in chamber of tumulus during excavations in 1890. Coll. by C. T. Le Roux and P. R. Giot; subm. 1963 by P. R. Giot. Comment: rather young.

\section{Saint-Brévin-L'Océan series, Loire Atlantique}

Bronze period coastal sites at Saint-Brévin-l'Océan $\left(47^{\circ} 12^{\prime} \mathrm{N}\right.$ Lat, $2^{\circ} 07^{\prime} \mathrm{W}$ Long). Flint splinters, many fragments of pottery, and statuette of baked clay found in the habitats (along the present beach), are supposed to be of Middle or Late Bronze period (Tessier, 1965). Coll. 1960 to 1962 and subm. 1963 by M. Tessier, Tharon, Loire Atlantique.

$\begin{array}{ll}\text { Gif-193A. Saint-Brévin-l'Océan, l'Hermitage, } & 3175 \pm 200 \\ & \text { S } 1960 .\end{array}$

Charcoal. 
Gif-193B. Saint-Brévin-l'Océan, l'Hermitage, S 1961.

$2775 \pm 200$

825 B.c.

Charcoal.

Gif-193C. Saint-Brévin-l'Océan, l'Hermitage, N 1962.

$2465 \pm 200$

515 B.c.

Charcoal.

$2720 \pm 200$

Gif-194. Saint-Brévin-l'Océan, La Roussellerie

770 B.c.

Carbonized corn.

General Comment: possible dates for a Late Bronze age. Variations between ages show a rather long occupation of these sites.

\section{Gif-236. Ancenis, Loire Atlantique}

$1820 \pm 200$

Oak wood of a dug-out canoe found buried in bed of Basse-Loire River during re-building of bridge of Ancenis $\left(47^{\circ} 22^{\prime} \mathrm{N}\right.$ Lat, $1^{\circ} 02^{\prime} \mathrm{W}$ Long). Coll. 1950 by M. Liot; subm. 1963 by P. R. Giot. At same level, fragments of a brain-pan of Bos primigenius.

\section{Mont-Saint-Michel series, Manche}

Mortars from walls of Notre-Dame-sous-Terre church, so-called Carolingian church. Church, on which was erected in IIth century the Romanic basilica of Mont-Saint-Michel, built on the rock itself $\left(48^{\circ} 38^{\prime}\right.$ $\mathrm{N}$ Lat, $10^{\circ} 30^{\prime} \mathrm{W}$ Long). Coll. and subm. 1964 by M. Traverse, Direction des Monuments Historiques de la Manche, J. Labeyrie and G. Delibrias.

Gif-314. Mont-Saint-Michel, E

$$
1150 \pm 120
$$

A.D. 800

Front $\mathrm{N}$ wall separating the 2 chapels, "chapelle de la Vierge" and "chapelle de la Trinité."

Gif-315. Mont-Saint-Michel, $\mathrm{C}$

Arcade N of "chapelle de la Trinité."

Gif-316. Mont-Saint-Michel, D
$1300 \pm 120$ A.D. 650

$$
1910 \pm 150
$$

A.D. 40

Wall W of "chapelle de la Vierge," mortar between bricks, at lowest part of wall.

General Comment: Gif-314 and Gif-315 clearly confirm that this now underground sanctuary is Carolingian and younger than the erection of the Roman basilica; they date it to the 8th and 9th centuries. Old date given by Gif-316 might indicate another much more ancient construction, unknown till now and partially re-used for foundation of the Carolingian church. These examples show that dating of old mortars made out of granitic sand may be very useful for achaeological determination (Froidevaux, 1961). 
Gif-190. Eglise Saint-Martin, Caen, Calvados

$1160 \pm 150$

Charcoal found under skeleton in cemetery surrounding old church of Saint-Martin at Caen $\left(49^{\circ} 11^{\prime} \mathrm{N}\right.$ Lat, $0^{\circ} 20^{\prime} \mathrm{W}$ Long). Coll. and subm. 1963 by M. de Boüard, Laboratoire d'Archéologie Médiévale, Faculté des Lettres, Caen, Calvados. Comment: these graves of sarcophagus type were surrounded by a set of goods dated archaeologically to 7 th century.

\section{Le Pontpiau-Champtocé series, Maine et Loire}

Charcoal found during excavation in grave of Pontpiau, Champtocé (47 ${ }^{\circ} 21^{\prime} \mathrm{N}$ Lat, $0^{\circ}$ 52' W Long) . Coll. 1961 and 1962, and subm. 1963 by M. Gruet, Musée de Paléonthologie, Angers, Maine et Loire.

\begin{tabular}{|c|c|}
\hline Gif-234A. & $\begin{array}{c}2755 \pm 150 \\
805 \text { в.с. }\end{array}$ \\
\hline Gif-234B. & $\begin{array}{c}2425 \pm 150 \\
475 \text { в.с. }\end{array}$ \\
\hline Gif-234C. & $\begin{array}{c}2620 \pm 150 \\
670 \text { в.C. }\end{array}$ \\
\hline Gif-234D. & $\begin{array}{c}2870 \pm 200 \\
920 \text { в.с. }\end{array}$ \\
\hline Gif-234E. & $\begin{array}{l}3160 \pm 200 \\
1210 \text { B.C. }\end{array}$ \\
\hline
\end{tabular}

General Comment: monument appears to have been re-occupied in Bronze period.

\section{B. Central and Eastern France}

Gif-209. Lac de Chalain, Doucier, Jura

Wood from pile-dwelling in Lac de Chalain at Doucier $\left(46^{\circ} 40^{\prime} \mathrm{N}\right.$ Lat, $1^{\circ} 06^{\prime} \mathrm{E}$ Long). Coll. 1934, $10 \mathrm{~m}$ from present shore, during a $2.50 \mathrm{~m}$ temporary lowering of the waters. Subm. 1961 by F. Tanazacq, Laboratoire de Géophysique de la Sorbonne, Paris. Comment: no archaeological contradiction.

\section{Forêt des Potées series, Maubert-Fontaine, Ardennes}

Charcoal from tumuli of Celtic necropolis at Forêt des Potées $\left(49^{\circ}\right.$ 52' $\mathrm{N}$ Lat, 0 12' E Long). Coll. 1939 by J. Hégly; subm. 1962 by $\mathrm{F}$. Tanazacq, Maubert-Fontaine, Ardennes.

Gif-210. Forêt des Potées, I-39-C $2020 \pm 150$

Hearse and incineration tumulus. 
Gif-211. Forêt des Potées, 5-39

$2530 \pm 150$

Total incineration tumulus.

580 B.c.

General Comment: shows that site has been used as necropolis during at least half a millenium.

\section{Gif-186. Lezoux, Puy de Dôme}

$800 \pm 120$

Charcoal found in the most recent soil, $1 \mathrm{~m}$ depth, of habitat erected upon remains of Roman-Gallic kiln of 2nd century A.D. at Lezoux $\left(46^{\circ}\right.$ 52' N Lat, 3० 33' E Long). Coll. 1964 by G. Fournier and subm. 1964 by E. Thellier, Institut de Physique du Globe, Paris. Comment: found with ceramics of Mediaeval type; date marks evolution of Roman-Gallic pottery to Mediaeval pottery.

\section{Gif-207. Ligugé, Vienne}

$1375 \pm 120$

Charcoal from mortar of Pre-Roman crypt of abbey of Ligugé $\left(46^{\circ}\right.$ $31^{\prime} \mathrm{N}$ Lat, $0^{\circ} 05^{\prime} \mathrm{E}$ Long). Coll. and subm. 1963 by Dom J. Coquet, Abbaye Saint-Martin, Ligugé, Vienne. Comment: agreement with archaeological age estimate.

\section{Coincy-en-Tardenois series, Aisne}

Samples from different layers of bed of Coincy, near Fère-en-Tardenois $\left(49^{\circ} 38^{\prime} \mathrm{N}\right.$ Lat, $3^{\circ} 23^{\prime} \mathrm{E}$ Long). place where the Tardenoisien defined (Alimen and others, 1964). Coll. and subm. 1961 by Hinout et $\mathrm{H}$. Alimen, Laboratoire de Géologie, C.N.R.S., Bellevue, Seine-et-Oise.

\section{Gif-131. Coincy-en-Tardenois, so-called place $\quad 3260 \pm 200$} "Le Géant"

1310 B.c.

Grave from base of peaty level overlying Tardenoisian industry.

\section{Gif-132. Coincy-en-Tardenois $\quad \mathbf{4 7 4 0} \pm \mathbf{3 5 0}$}

Hearth No. 2 "La Chambre aux Fées" 2790 B.c. dustry.

Charcoal, found at 60 to $80 \mathrm{~cm}$ depth, mixed with Tardenoisian in-

Gif-133-134. Coincy-en-Tardenois

$5040 \pm 500$ Hearths No. 3 and 4 "La Chambre 3090 B.c. aux Fées"

Charcoal from two different hearths, No. 3 and 4 , at 60 to $70 \mathrm{~cm}$ depth with a distance of $1.50 \mathrm{~m}$ between them, mixed with Tardenoisian industry, at horizontal distance of $15 \mathrm{~m}$ from Gif-131 and Gif-123. Comment: these two scarce samples have been added together. Besides, filling of the counter has been completed with inert $\mathrm{CO}^{2}$; thus this measurement is more imprecise.

General Comment: Gif-132 and 133-134 are the first absolute datings of this layer eponymous of the Tardenoisian. 
Gif-272. Combe Barre T3, Darcey, Côte d'Or

Charcoal from hearth at base of tumulus of Iron period at Combe Barre T3, Darcey (47 $34^{\prime} \mathrm{N}$ Lat, $4^{\circ} 34^{\prime} \mathrm{E}$ Long). Coll. 1962 and subm. 1965 by Abbé Joly, Antiquités Préhistoriques de Dijon.

Gif-247. Sublaines, Indre et Loire

$950 \pm 150$

Bone in a crushed urn found at $1.70 \mathrm{~m}$ depth in Merovigian cemetery of Sublaines $\left(47^{\circ} 16^{\prime} \mathrm{N}\right.$ Lat, $0^{\circ} 59^{\prime} \mathrm{E}$ Long) (Cordier and Eygun, 1963). Coll. 1962 and subm. by G. Gordier, Beaulieu-lès-Loches, Indre et Löire. Comment: measurement has not been done on the collagene, but on the whole bone. Initially thought to be of Iron age but in reality dated from 7 th century A.D.

\section{Beaussement series, Chauzon, Ardèche}

Charcoal from station surrounded by dry stones and big blocks of stones stretched over many thousands of m2. Ferrières' characteristic ceramics (44 $32^{\prime} \mathrm{N}$ Lat, 4 21' E Long). Coll. 1963 and subm. 1964 by R. Montjardin, Lycée Technique d'Arles, Bouches-du-Rhône.

Gif-245. Beaussemant S-3 - C4/6

Boring 3, Layer $4 / 6$.

2150 B.c.

Gif-246. Beaussement S.4 - C4

Boring 4, Layer 4.

Comment: Southern Late Neolithic of Early Ferrières group (Montjardin, 1962).

\section{Southern and South-Eastern France}

Gif-72. La Bonne Mère, Bouches-du-Rhône

500 B.c.

Human bones discovered at base of rocky spur on skirts of Etang de Berre, at La Bonne Mère, Marignane, Bouches-du-Rhône $\left(43^{\circ} 25^{\prime} \mathrm{N}\right.$ Lat, $5^{\circ} 10^{\prime} \mathrm{E}$ Long). Coll. 1959 and subm. by O. Sicard, Les Plaines, Marignane. Comment: no clue about date of these bones.

\section{Gif-156. Lebous, Saint-Mathieu de Treviers, Hérault 1930}

Charcoal from surface layer, under Tower 1 of monument of Lebous, Saint-Mathieu de Treviers (43 $36^{\prime}$ N Lat, $3^{\circ} 51^{\prime}$ E Long) (Arnal and others, 1964). Coll. and subm. 1962 by J. Arnal. Comment: industries of old Bronze period: daggers, needles, and pottery with fragments of a skeleton enable us to date site to end of Chalcolithic period. Monument, being really a fortification, shows an architecture which is, presently, the only one found at this period. Good agreement between $\mathrm{C}^{14}$ and archaeologic dates for this Chalcolithic monument. 


\section{Saint-Etienne de Gourgas series, Hérault}

Charcoal from prehistoric hearth found under rocky shelter close to an oppidum at Saint-Etienne de Gourgas ( $43^{\circ} 46^{\prime}$ N Lat, $3^{\circ} 23^{\prime}$ E Long) (Escalon de Tonkan, 1963). Coll. and subm. 1962 by G. Arnal, Lodève, Hérault.

\section{Gif-154a. Saint-Etienne de Gourgas F.14 \\ $3880 \pm 250$ 1930 B.C. \\ Gif-154f. Saint-Etienne de Gourgas F.18 \\ $3780 \pm 250$ \\ 1780 B.c. \\ Gif-154i. Saint-Etienne de Gourgas F.22 \\ $4570 \pm 300$ \\ 2620 B.C.}

General Comment: 154i dates Hearth F.22 which corresponds to Chassean level of site while 154a is clearly marked by recent Neolithic and material contemporary with the monument of Lebous, Gif-156: $3880 \pm$ 250.

\section{Gif-96. Lasalle, Gard}

A.D. 1800

$150 \pm 100$

Wood from vaulted cistern between l'Estréchure and Col de Marcou, at Lasalle $\left(44^{\circ} 05^{\prime} \mathrm{N}\right.$ Lat, $3^{\circ} 45^{\prime} \mathrm{E}$ Long). Coll. 1960 and subm. by P. Monnet, Eaux et Forêts, Gap, Hautes Alpes. Comment: building of unknown age, and technically interesting.

Gif-191. Grotte de Prével, Montclus, Gard

$3880 \pm 180$

1930 B.c.

Carbonized fruits found in clayey layer at $1 \mathrm{~m}$ depth in cave of Préval, commune de Montclus $44^{\circ} 16^{\prime} \mathrm{N}$ Lat, $4^{\circ} 25^{\prime} \mathrm{E}$ Long). An important industry has been found in this layer, including polished stone axes, foliated arrows, and copper needles; dated in Eneolithic age (Roudil, 1963). Coll. and subm. 1962 by J. L. Roudil, C.N.R.S. Montpellier, Hérault.

\section{Aiguebelette series, Lac d'Aiguebelette, Savoie}

Wood of pile-foundation at coastal station presently under ca. $2 \mathrm{~m}$ water in lake of Aiguebelette ( $45^{\circ} 32^{\prime} \mathrm{N}$ Lat, $5^{\circ} 43^{\prime} \mathrm{E}$ Long). Coll. and subm. 1962 by R. Laurent, Centre de Recherches Archéologiques Lacustres de Dauphiné-Savoie, Tresserve, Savoie.

Gif-222. Aiguebelette I, 601-D

$2480 \pm 150$

South part of station.

Gif-223. Aiguebelette Ibis, 605B

contemporary

On hillock at $350 \mathrm{~m}$ from Aiguebelette I. Comment: supposed age similar to Gif-222. Probably recent pile fixed up into hillock by fishermen. 
General Comment: this Chalcolithic station is contemporary with other lake dwellings of area, particularly at Thonon, lake of Geneva (Sa-228: $2440 \pm 180$, Saclay II). None of the lithic implements of this station have been found up to now.

\section{Gif-202. La Thuile, Beaumont, Haute-Savoie}

$1615 \pm 120$

Charcoal, 0.60 to $0.70 \mathrm{~m}$ depth, found under an accumulation of scoria and debris of kiln at La Thuile $\left(46^{\circ} 05^{\prime} \mathrm{N}\right.$ Lat, $1^{\circ} 27^{\prime} \mathrm{E}$ Long), Beaumont, alt $1.260 \mathrm{~m}$ in the Alps. Coll. 1959 and subm. 1963 by H. Armand, Annecy, Haute-Savoie. Comment: this is an old working ironmine and date found corresponds to most recent of the supposed dates for this type of exploitation.

\section{Gif-217. La Condamine, Ladern-sur-Lauquet, Aude \\ $1680 \pm 150$ \\ A.D. 270}

Charcoal from Chalcolithic open-air station at La Condamine $\left(46^{\circ}\right.$ $6^{\prime} 5^{\prime \prime} \mathrm{N}$ Lat, 2० 21' 50" E Long). Coll. 1962 and subm. 1963 by J. Guilaine, C.N.R.S. Carcassonne. Comment: it seems clear that there has been a contamination of the station by more recent charcoal.

Gif-218. Shelter Jean Cros, Labastide-en-Val, Aude

$6500 \pm 300$

4550 B.c.

Charcoal from rock shelter Jean Cros, Labastide-en-Val $\left(43^{\circ} 05^{\prime} \mathrm{N}\right.$ Lat, $2^{\circ} 28^{\prime}$ E Long). Coll. and subm. 1963 by J. Guilaine. Comment: the layer from which charcoal was extracted has yielded an industry of Mesolithic tradition.

Gif-258. La Valette, Veraza, Aude

Charcoal of Cave III at La Valette, Veraza $\left(47^{\circ} 47^{\prime} \mathrm{N}\right.$ Lat, $0^{\circ} 5^{\prime} \mathrm{E}$ Long). Coll. 1963 and subm. 1964 by J. Guilaine. Comment: site contains Chalcolithic remains, but was probably re-occupied later.

\section{Corsica and Sardinia}

\section{Filitosa series, Sollacaro, Corsica}

Charcoal from circular monuments with outbuilding "Torri" at Filitosa, Vallée du Tavaro (41 $43^{\prime} \mathrm{N}$ Lat, $8^{\circ} 51^{\prime} \mathrm{E}$ Long). Ca. 10 of these monuments found in the valley. They certainly had a funerary purpose, as debris of bones have been collected at Filitosa and Cucurruzzu with goods of Bronze period (Grosjean, 1961, 1964). Coll. and subm. 1962 by R. Grosjean, C.N.R.S., Paris.

Gif-150. Filitosa CB

$2550 \pm 170$

600 B.C.

Bottom of Hut B, Torrean habitat of site. Comment: re-utilization of site has already been dated: 3220 B.P. (Gsy-58, Gif I). 
Gif-151. Musolo, Sollacaro

$1540 \pm 150$

Charcoal from site of Musolo, Valley of Tavaro $\left(41^{\circ} 40^{\prime} \mathrm{N}\right.$ Lat, $8^{\circ}$ $50^{\prime}$ E Long), Sollacaro; with a statue menhir. Comment: evident contamination.

\section{Nuraghes series, Sardinia}

Charcoal from nuraghes, which are fortresses with corridors in Sardinia. In these monuments, similar to Corsican torri, have been found a set of goods like those found at Cucurruzzu. Subm. by R. Grosjean.

Gif-242. Nuraghe Albucciu, Sassari, Sardinia

$3170 \pm 250$ by Rerranese Ceruti.

Gif-243. Nuraghe Brunku Màdili 1 and 2, Gesturi, Cagliari

$3770 \pm 250$

Layer e. Coll. 1962-1963 by Pr. Lilliu.

General Comment: dates earliest nuraghes of Sardinia, at least $600 \mathrm{yr}$ before torri of Corsica (Gif-150, 239 and 241).

\section{Cucuruzzu series, Lévie, Sartène, Corsica}

Charcoal from torri citadel of Middle Bronze period at Cucuruzzu, Lévie, between Porto-Vecchio group and S. O. part of Corsica. Goods of Bronze period. Coll. and subm. 1963 by R. Grosjean.

Gif-239. Cucuruzzu 1

Corridor G. 1 inferior.

Gif-241. Cucuruzzu 3

Aeria B. C. II, inferior, part Ba.

Comment: consistent with Filitosa dating (Gif-150).

\section{Gif-83. Tibesti, Saraha}

$$
\text { E. Africa }
$$

Human brain-pan found in recent depression dug in post-Tassilien and filled by faded brownish clay at $\mathrm{E}$ of Tibesti, $\mathrm{S}$ of Bassin of Koufra, at frontier of Libya-Tchad $\left(22^{\circ} 30^{\prime} \mathrm{N}\right.$ Lat, $14^{\circ} \mathrm{E}$ Long); with Lamellibranches, fresh water shells. Coll. and subm. 1960 by S. Arnould-Saget, Service Géologique, Compagnie Française des Pétroles, Paris. Comment: dates last Saharian pluvial.

\section{Tassili-n-Ajjer series, Sahara}

Samples coll. in Tassili in 1962 by the mission of $\mathrm{H}$. Lhote and subm. by H. Lhote, 1964. Many marks of this Neolithic highly-cultured 
central part of the Sahara, such as implements and potsherds found in natural cliff shelters. Beautiful paintings representing bulls, cows, etc. covered walls of these shelters. All charcoal from local hearths in archaeological layer which is found between 2 layers of sterile silt, 10 to $20 \mathrm{~cm}$ thick, covered with another layer of goat and cow manure and topped by sand of Eolian origin. Palynologic study of archaeological layers is in progress; betula has already been found.

\section{Gif-286. Station of Initinen No. 1}

$4860 \pm 250$

From $24^{\circ} 41^{\prime} \mathrm{N}$ Lat, $9^{\circ} 41^{\prime}$ E Long. Charcoal from Hearth No. 1.

Gif-287. Station of Initinen No. 2 $4630 \pm 250$

Charcoal from Hearth No. 2. 2680 B.C.

Gif-288. Station of Titerast-n-Elias, No. 3 $4560 \pm 250$ 2610 B.c.

From $24^{\circ} 39^{\prime} \mathrm{N}$ Lat, $9^{\circ} 41^{\prime} \mathrm{E}$ Long. Charcoal from hearth bordered by a stone circle, inside a shelter with painted walls. Comment: pottery and cow bones found in vicinity of hearth. The paintings of cows are probably of same period as hearth.

Gif-289. Station of Initinen, No. 8

$2250 \pm 200$

300 B.C.

Whitish paint of animal origin covering wall-pictures of one shelter. Comment: this date gives minimum age of this paint which is, in fact, probably much older, even "pre-Bovidian" according to archaeological inference.

Gif-290. Station de Titerast-n-Elias, No. 5 $7400 \pm 300$ $\mathbf{5 4 5 0}$ B.c.

Charcoal from another hearth of same type. Comment: date is oldest ever found for Tassili human occupation. Oldest dates previously published were 4270 and 5470 (Sa-65, Sa-66, Saclay I).

Gif-291. Station of the Titerast-n-Elias, No. 6

$$
2500 \pm 200
$$

500 в.c.

Charcoal from upper-level. Comment: this hearth, by its level, seems to correspond to a second period of occupation of the site.

\section{Gif-292. Station of Ekaham}

$$
4470 \pm 250
$$

Gif-292. Station of Ekaham-ouan-Tartaït, No. $7 \quad 2520$ B.c.

From $24^{\circ} 42^{\prime} \mathrm{N}$ Lat, $9^{\circ} 39^{\prime} \mathrm{E}$ Long. Charcoal in archaeological layer of a huge shelter with wall paintings.

\section{Gif-155. Ferkane, Tebessa, Algeria}

$$
1950 \pm 150
$$

A.D. 1

Charcoal from tumulus at Ferkane, Tebessa $\left(34^{\circ} 33^{\prime} \mathrm{N}\right.$ Lat, $7^{\circ} 25^{\prime}$ Long). Coll. 1961 by Grébénart; subm. 1961 by G. Camps, Cēntre de Recherches Anthropologiques Préhistoriques et Ethnographiques, Le 
Bardo, Alger. Comment: one of the 201 protohistoric sepultures under tumulus found up to now in region of Ferkane. Skeleton was surrounded by big blocks of stones forming a chest and placed in centre of tumulus. The dated charcoals were mixed with filling sand of chest.

\section{Tegdaoust series, Mauritanie}

Mixed coals, bones, and straw found at Tegdaoust $\left(17^{\circ} \mathrm{N} \mathrm{Lat,} 12^{\circ}\right.$ W Long). Site supposed to be that of ancient big African town called Aoudaghost. Coll. and subm. 1964 by J. Devisse, Université de Dakar, Fann, Dakar.

Gif-265. Tegdaoust, No. 339

$650 \pm 120$

Mixed coal with bones from a fireplace at $3 \mathrm{~m}$ depth, House II.

Gif-266. Tegdaoust, No. 504K

Modern

$2.75 \mathrm{~m}$ depth.

General Comment: a pit, $1.50 \mathrm{~m}$ depth was dated $150 \pm 100$ (Sa-219, Saclay I).

Gif-304. Abri du Sous-Marin, Tamanrasset, Hoggar $\begin{array}{ll}4720 \pm 30 \text { B.C. } & \mathbf{2 7 7 0}\end{array}$

Coal from hearth of archaeologic layer at shelter "du Sous-Marin," Tamanrasset $\left(23^{\circ} 10^{\prime} \mathrm{N}\right.$ Lat, $5^{\circ} 35^{\prime} \mathrm{E}$ Long). Coll. and subm. 1964 by G. Camps. Comment: confirms dates already known archaeologically as Neolithic.

\section{Gif-305. Tombeau de la Chrétienne, Bérard, $1660 \pm 120$ Algiers \\ A.D. 290}

Wooden cramp joining together calcareous blocks of a Berber preroman mausoleum, Le Tombeau de la Chrétienne, Bérard, Algiers (36 ${ }^{\circ}$ 34' N Lat, 2० 33' E Long). Coll. 1940 by M. Christofle; subm. 1963 by G. Camps. Comment: construction supposed to be of the lst century B.C.; result is unexplained.

\section{$F$. Other countries}

$$
9470 \pm 400
$$

Gif-130. Caverne de Santimamiñe, Cortézubi, Spain 7520 B.c.

Bones of different animals from hearths found in archaeological layer No. 7 of Santimamiñe cave, Cortézubi, Biscaye $\left(43^{\circ} 17^{\prime} \mathrm{N}\right.$ Lat, $3^{\circ}$ 01' W Long). Coll. 1960 by J. M. de Barandraran; subm. 1961 by P. Marquer, Laboratoire d'Anthropologie, Musée de l'Homme, Paris. Comment: would correspond better to supposed age of Layer 6 (Magdalenian) of this cave.

\section{Tumulus de la Païta series, Nouvelle Calédonie}

Many tumuli, similar to those already discovered in Island of the Pines, $70 \mathrm{~km}$ from Nouvelle, Calédonie, have been found lately at Païta 
$\left(22^{\circ} 08^{\prime} \mathrm{S}\right.$ Lat, $166^{\circ} 28^{\prime} \mathrm{E}$ Long), Nouvelle Calédonie. These tumuli, max. height $2.50 \mathrm{~m}$ with a base 10 to $12 \mathrm{~m}$ in diam, have been built of small regular gravel of iron oxide in the Ile des Pins and with siliceous sand near Païta. In the central part stands a cylinder, 1 to $2 \mathrm{~m}$ in diam and 1 to $2.50 \mathrm{~m}$ high, made homogeneously of a hard lime mortar in which have been found shells. Neither implements, bones, or charcoal found there up to now. Up to 1964, 400 tumuli have been recorded on the Ile des Pins and 17 on the Nouvelle Calédonie Island; only four have been excavated: three contain single mortar-libre cylinders and the other two. Origin and significance of these tumuli are completely unknown. Monuments testify to an important human activity completely extinct today in Nouvelle Calédonie and in Ile des Pins (Chevalier, 1964). Coll. and subm. 1963 by L. Chevalier, Musée Néo-Calédonien de Nouméa, Nouvelle Calédonie.

Gif-298. Tumulus of Païta, I

$12,900 \pm 450$

Placostylus shells tied to mortar on surface of central cylinder in tumulus.

Gif-299. Tumulus of Païta, II

$\mathbf{7 0 7 0} \pm 350$

Mortar from surface of cylinder, tied to placostylus shells.

Gif-300. Tumulus of Païta, III

$9600 \pm 400$

Mortar from interior of cylinder.

General Comment: although results are not very homogeneous, if cylinders are really man-made mortars, they are by far the most ancient mortars known. They are believed to be mortars and not transported stones cut out of limestone or local natural formation because external parts of cylinders contain many bits of silica gravel (Païta) or of iron oxide gravel (Ile des Pins), as if liquid mortar had been poured in hole previously dug in tumulus of gravel and then allowed to solidify "in situ." On the other hand, the fact that mortar had not been dissolved during long exposition to tropical climate, is probably explained by siliceous sand or iron oxide sand, of which the tumuli are made, being very arid soil. Incidentally, present people of islands know lime and mortar fabrication only from missionaries' arrival in 18th century.

\section{GEOLOGIC SAMPLES}

\section{A. France}

Gif-341. Couternon, Côte d'Or, 2

$9440 \pm 350$

7490 B.C.

Fragment of Pinus sylvestris from clayey level covered with $2.50 \mathrm{~m}$ rough gravels and $0.50 \mathrm{~m}$ arable ground in forest "Les Sablières" at Couternon $\left(47^{\circ} 19^{\prime} \mathrm{N}\right.$ Lat, $5^{\circ} 09^{\prime} \mathrm{E}$ Long). At same level, Elephas primi- 
genius. Coll. 1962 and subm. 1965 by Abbé Jolly. Comment: supposedly dates period before deglaciation, but date makes this unlikely.

\section{Gif-342. Mammoth tooth, Manche}

$8720 \pm 300$

6770 B.c.

Mammoth tooth found by fishermen trawling at $60 \mathrm{~m}$ depth in $\mathrm{La}$ Manche $\left(50^{\circ} 27^{\prime} \mathrm{N}\right.$ Lat, $0^{\circ} 25^{\prime} \mathrm{W}$ Long) in site where many remains of mammoths have been found. Subm. by C. Larsonneur, Institut de Géologie et de Paléontologic, Caen, Calvados. Comment: supposedly dates maximum limit of seashore before post-Würmian marine transgression, but anomalous young age suggests contamination. Organic fraction was too small to be dated so total carbonate was used.

\section{Gif-340. Forêt de Fontainbleau, Seine et Marne $\quad \begin{aligned} 2075 & \pm 150 \\ & 125 \text { B.c. }\end{aligned}$}

Debris of carbonized tree-branches from burnt level of podzol under dune, $2 \mathrm{~m}$ thick, and topped with present Fontainbleau forest $\left(48^{\circ} 26^{\prime}\right.$ $\mathrm{N}$ Lat, $2^{\circ} 40^{\prime} \mathrm{E}$ Long). Level corresponds to horizon Ao-1 of podzol dune. Coll. and subm. 1964 by C. Allier, Ecole Normale Supérieure de Saint-Cloud, Seine. Comment: gives maximum age for emplacement of dune.

\section{Prémery series, Nièvre}

Sphagnum peat in small depression topping a hill in forest of Prémery (47 $12^{\prime} \mathrm{N}$ Lat, $3^{\circ} 18^{\prime} \mathrm{E}$ Long), S of Basin of Paris. Coll. 1962 and subm. 1963 by R. Braque, Nevers, Nièvre.

\section{Gif-199. Prémery No. 1}

Pine-wood, $1.30 \mathrm{~m}$ depth, in silt-layer under peaty level.

Gif-200. Prémery No. 2

$4680 \pm 300$

2730 B.c. deposit.

Wood, $0.85 \mathrm{~cm}$ depth, at the base of peaty level; in contact with silt

\section{Gif-201. Prémery No. 3}

$3500 \pm 250$

Grey silt, peaty at $0.90 \mathrm{~cm}$ depth.

Comment: age of Gif-199 is identical with Sa-247 (7550 \pm 350 , Saclay II) for grey silt at $1.20 \mathrm{~m}$ depth. Pollen analysis of this silt has indicated Boreal period. Rather young age of Gif-201 could be explained by penetration of roots, sampling being at $5 \mathrm{~cm}$ under base of peaty level. Gif-200 could date end of silt sedimentation.

\section{Coastal peat of Normandy series}

Organic deposits of fresh or brackish water along coast sheltered from sea by line of drowned sandhills reaching to -1 to $-2.50 \mathrm{~m}$ depth 
below spring tide level. Pollen analysis: H. Elhai (Elhai, 1963). Coll. and subm. 1963 by H. Elhai, Institut de Géographie, Paris.

Gif-169. Appeville 1, Manche

$2100 \pm 140$

150 B.c.

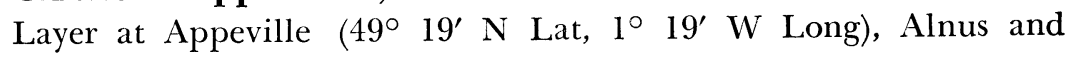
Quercus predominating.

\section{Gif-171. Le Becquet, Manche}

$2130 \pm 150$

Layer at Le Becquet $\left(49^{\circ} 39^{\prime} \mathrm{N}\right.$ Lat, $1^{\circ} 34^{\prime} \mathrm{W}$ Long), Quercus and Betula predominating.

\section{Gif-172. Nacqueville, Manche}

$2130 \pm 150$

180 B.c.

Layer at Nacqueville (49 $40^{\prime} \mathrm{N}$ Lat, $1^{\circ} 44^{\prime} \mathrm{W}$ Long), in which have been found a Gallic coin and Roman millstones. Quercus and Betula largely predominating.

Gif-173. Saint-Pair 5

$3060 \pm 160$

1110 B.c.

Deposit at $30 \mathrm{~cm}$ depth, alt $85 \mathrm{~m}$ above sealevel in present sandhill at Saint-Pair $\left(48^{\circ} 48^{\prime} \mathrm{N}\right.$ Lat, $1^{\circ} 34^{\prime} \mathrm{W}$ Long). Quercus and Betula predominating with abundant Titiolum.

General Comment: confirmation of conclusions made after pollen analysis: formation of near-tidal deposits at end of Sub-Boreal or at beginning of Sub-Atlantic. For Saint-Pair, age corresponds to a different and older forest marked by absence of beech.

\section{B. Spitsbergen}

\section{La Baie du Roi series, Spitsbergen}

Shells from marine terrace raised by isostatic post-glacial movements in Barents sea, Baie du Roi $\left(78^{\circ} 55^{\prime} \mathrm{N}\right.$ Lat, $12^{\circ} 05^{\prime} \mathrm{W}$ Long), Spitsbergen. Coll. and subm. J. Corbel, Recherches Interdisciplines sur les Hautes Latitudes, C.N.R.S., Paris.

Gif-317. La Baie du Roi, I

$9260 \pm 350$

7310 B.c.

$\mathrm{W}$ terrace of French base, alt $11 \mathrm{~m}$.

Gif-318. La Baie du Roi, II

E terrace of French base. Base of cliff, alt $13 \mathrm{~m}$.

Gif-319. La Baie du Roi, III
$9350 \pm 350$

7400 B.c.

$9650 \pm 350$

7700 B.C.

Upper terrace, right bank of river La Goule, alt $20 \mathrm{~m}$.

General Comment: rates of isostatic uplift of main island of Spitsbergen may be deduced from these values. If we adopt, from the above values, mean position of $-14 \mathrm{~m}$ for eustatic sealevel $9300 \mathrm{yr}$ ago, and if we take 
from Gif-318 a total differential uplift of $15 \mathrm{~m}$ ( $13 \mathrm{~m}$ plus the $2 \mathrm{~m}$ mean depth where shells are supposed to have lived before uplift), we deduce a total isostatic uplift of this region of $14+15=29 \mathrm{~m}$. Therefore, the mean rate from 9300 B.P. till now is $29 / 93=0.31 \mathrm{~m}$ per century. On the other hand, about 9300 yr ago the 3 dates show that mean differential uplift was much faster, ca. $2.2 \mathrm{~m}$ per century, than the mean since that time (Washburn and Stuiver, 1962).

\title{
Saoura series, Sahara
}

$$
\text { C. Africa }
$$

Mollusc shells from different layers of Saourian formations. Date phases of last great Saharan sedimentary period. Coll. and subm. 1963 by H. Alimen, Lab. de Géologie du Quaternaire, C.N.R.S., Bellevue, Seine et Oise.

\section{Gif-213. Hassi Zgilma, Saoura, 543}

$9030 \pm 400$ Long).

\author{
Layer Ia, $1.80 \mathrm{~m}$ depth, at Hassi Zgilma $\left(30^{\circ} 13^{\prime} \mathrm{N}\right.$ Lat, $2^{\circ} 29^{\prime} \mathrm{W}$
}

Gif-214. Hassi Zgilma, Saoura, 544

Layer Ib, $1.50 \mathrm{~m}$ depth.

\section{Gif-215. Hassi Zgilma, Saoura, 545}

Layer H, $1 \mathrm{~m}$ depth, sandy marl, would correspond to a Guirien; a Neolithic piece of silex has been found in this layer.

\section{Gif-216. El Ouata, Saoura, 556}

Fossil level, Layer A, $6 \mathrm{~m}$ depth. Saourian formations at El Ouata $\left(2^{\circ} 52^{\prime} \mathrm{N}\right.$ Lat, $1^{\circ} 50^{\prime} \mathrm{W}$ Long) are 17 to $20 \mathrm{~m}$ thick. Comment: consistent with other dates of last great Saharan pluvial period (Gif-285, 83 this date list).

\section{Hoggar series, Sahara Central}

Calcareous lake formations set in crystalline rocks in bottoms of valleys of Hoggar. Fresh water molluscs (physids, succineids and planorbids) have been found in this formation which is at 1 or $2 \mathrm{~m}$ above present bed of wadi. Calcium of this calcareous deposit seems to have been mobilized when the country rock (basalt) was altered during or before a damp period (Delibrias and Dutil, 1965) ; with lacustrine sediments, it now forms a lacustrine limestone. Coll. 1962 and subm. 1964 by P. Dutil, Centre de Recherche Agronomique du S. O. Bordeaux, Girdonde.

Gif-325. Région d'Hirafok-S.476

$\mathbf{8 3 8 0} \pm 300$

Alt: ca. $1450 \mathrm{~m}$ (23 $39^{\prime} \mathrm{N}$ Lat, $5^{\circ} 40^{\prime}$ E Long).

6430 B.c. 
Gif-326. Oued Irzerzou-S.483

$11,580 \pm 350$

Alt: ca. $1300 \mathrm{~m}$ (220 $44^{\prime} \mathrm{N}$ Lat, $5^{\circ} 23^{\prime} \mathrm{E}$ Long).

9630 B.c.

General Comment: makes clear that there was a damp climate in Central Hoggar between 8000 and 11,000 B.P.; in good correlation with age found for carbonates of diatomites of Agadem, E Niger, Africa $\left(16^{\circ} 50^{\prime}\right.$ $\mathrm{N}$ Lat, $13^{\circ} 20^{\prime} \mathrm{E}$ Long): T-338 A, $8580 \pm 110$ (Trondheim IV; see also Faure et al., 1963).

\section{Gif-76. Ténéré, Niger Oriental}

$3350 \pm 200$

1400 B.c.

Hippopotamus bone from dwellings built over diatomaceous deposits, which were later covered by recent dunes, $30 \mathrm{~km} \mathrm{~W}$ of Fachi, Ténéré $\left(18^{\circ} 06^{\prime} \mathrm{N}\right.$ Lat, $11^{\circ} 18^{\prime} \mathrm{E}$ Long). Coll. 1955 and subm. 1960 by H. Faure, Lab. de Géologie, Univ. de Dakar, Sénégal. Comment: existence of hippopotamus in region at this time indicates that large lakes, known to have existed before the Neolithic, had not yet dried, or perhaps had reformed during a short damp pulsation during general drying of S Sahara.

\section{$3180 \pm 200$ \\ Gif-284. Puits d'Achegour, Ténéré, Niger No. 39021230 B.c.}

Shells of lacustrine bivalves imbedded in nonfissile, impure diatomite at $390 \mathrm{~m}$ alt, $25 \mathrm{~km} \mathrm{SW}$ of Puits d'Achegour ( $18^{\circ} 51^{\prime} \mathrm{N} \mathrm{Lat}, 11^{\circ}$ 36' E Long) Ténéré. Coll. 1963 and subm. 1964 by H. Faure. Comment: to be compared to diatomite layer dated as 3350 B.P., Gif-76, this date list. Confirms persistence of damp conditions in this part of Ténéré, now an extremely dry desert.

\section{Gif-285. Cliff of Kaodi, Oasis of Fachi, Ténéré, $\quad \mathbf{8 5 0 0} \pm 35$ Niger, No. 4005 \\ 6550 B.C.}

Shells of freshwater Melania tuberculata (gastropod) at foot of diatomite layer outcropping in main cliff of Kaodi $\left(18^{\circ} 07^{\prime} \mathrm{N}\right.$ Lat, $11^{\circ} 37^{\prime}$ E Long), oasis of Fachi, Ténéré. Coll. 1963 and subm. 1964 by H. Faure. Comment: morphologic situation of this shell-level, $25 \mathrm{~m}$ above present bottom of basin, indicates deposition at time of the lake's maximum extension. Consistent with very damp climate in South Sahara during this period.

\section{Gif-221. Pointe-Noire, Brazzaville, Congo}

$7200 \pm 300$

Wood from recent marine sediments, $7 \mathrm{~m}$ depth, found in bay of Pointe-Nore ( $4^{\circ} 47^{\prime} \mathrm{S}$ Lat, $11^{\circ} 50^{\prime} \mathrm{E}$ Long). Coll. during dredgings at $500 \mathrm{~m}$ off shore in water $12 \mathrm{~m}$ deep. Subm. 1964 by J. Herman, Direction of the Harbour of Pointe-Noire, Brazzaville. Comment: measurement required during harbour work in order to estimate stability of sediments. Results show low rate of sedimentation and imply adequate stability. 


\section{Nouvelles Hébrides}

\section{Ile de Tongoa series, Nouvelles Hébrides}

Charcoal found under pumice and tuffs at island of Tongoa $\left(16^{\circ}\right.$ 55' S Lat, $168^{\circ} 35^{\prime}$ E Long). Coll. 1962 and subm. 1964 by B. Gèze, Lab. de Géologie, Institut Nat. Agronomique, Paris.

Gif-259. Tongoa, Moerin 1

Alt: $100 \mathrm{~m}$.

Gif-260. Tongoa, Moerin 2

Alt: $5 \mathrm{~m}$.

Gif-261. Tongoa, Mangarisiu

Comment: dates last major volcanism in Nouvelles Hébrides.

Date lists:

Saclay I Delibrias, Guillier and Labeyrie, 1964

Saclay II Delibrias, Guillier and Labeyrie, 1965

Trondheim IV Nydal, Lövseth, Skullerud, and Holm, 1964

Alimen, M., Delibrias, G., Sauvage, J., 1964, Géologie, chronologie et palynologie de la station tardénoisienne de Coincy: Gallia-Préhistoire, v. 7, p. 95-105.

Arnal, J., Martin-Gravel, M., Sangmeister, E., 1964, Lébous: Antiquity, v. 38, p. 191-200. Chevalier, L., 1964, Revue de la Société d'Etudes Mélanésiennes: Etudes Mélanésiennes, Nouméa, p. 24-45.

Cordier, G., Eygun, F., 1963, Informations Archéologiques: Gallia XXI, p. 449-450.

Delibrias, G., Dutil, P., 1965, Formations calcaires lacustres du Quaternaire Supérieur dans le Massif Central Saharien (Hoggar) et datations absolues: Comptes Rendus de l'Acad. des Sci., v. 262, p. 55-58.

Delibrias, G., Elhaï, H., 1965, Age absolu de tourbes littorales en Normandie: CompteRendu à l'Académie des Sciences de Paris, v. 260, p. 2872-2873.

Elhaï, H., 1963, La Normandie Occidentale: Imprimerie Bière, Bordeaux, p. 214-245.

Escalon de Toukan, M., 1963, Informations Archéologiques: Gallia-Préhistoire, v. 6, p. 240-241.

Faure, H., Manguin, Nydal, R., 1963, Formations lacustres du Quaternaire Supérieur du Niger oriental: Diatomites et âges absolus: Bull. B.R.G.M. no. 3.

Froidevaux, Y., 1961, l'Eglise Notre-Dame-sous-Terre de l'Abbaye du Mont-SaintMichel: Les Monuments Historiques de France, no. 4, p. 144-166.

Giot, P. R., 1964, Les lingots de fer bipyramidaux de Bretagne: Annales de Bretagne, v. 71 , p. $51-60$.

1965, Chroniques des Datations Radiocarbone Armoricaines: Annales de Bretagne, v. 72, p. 133-147.

Grebenart, D., 1961-1962, Sépultures protohistoriques de la région de Ferkane: Libyca, v. 9-10, p. 171-195.

Grosjean, R., 1961, Filitosa et son contexte: Monuments et Mémoires, v. 52, 102 p. 1964, Filitosa-Haut lieu de la Corse préhistorique: Notice Archéologique, $32 \mathrm{p}$.

Lagrand, C. M., 1962, Recherches sur le Bronze Final dans les Gorges du Verdon: Cahiers Ligures de Préhistoire et d'Archéologie, v. 11, p. 263. 
L'Helgouach, J., Le Roux, C. T., 1965, La Sépulture mégalithique à entrée latérale du Champ-Grosset en Quessoy (Côtes du Nord): Annales de Bretagne, v. 72, p. 5-31. Montjardin, R., 1962, Le peuplement préhistorique d'un plateau de la basse Ardèche: Chauzon: Cahiers Rhodaniens, v. 4, p. 1-52.

Roudil, J. L., 1964, Grotte du Preval. Montclus gard.: Cahiers Ligures de Préhistoire et d'Archéologie, 1963, v. 12, p. 233-238; v. 13, p. 276-277.

Pequart, M., and S. J., 1954, Hoëdic, deuxième station-nécropole du Mésolithique côtier armoricain: Anvers, De Sikkel, Ed.

Tessier, M., 1965, Sites côtiers de l'Age de Bronze du Pays de Retz: Annales de Bretagne, v. 72, p. 75-85.

Van Zeist, W., 1963, Recherches Palynologiques en Bretagne occidentale: Norois, v. 10 , p. 5-19.

Washburn, A. L., and Stuiver, Minze, 1962, Radiocarbon-dated postglacial delevelling in northeast Greenland and its implications: Arctic, v. 15, p. 66-73. 